\title{
THE FEDERAL ROLE IN THE WAR ON POVERTY PROGRAM
}

\author{
RICHARD H. LEACH*
}

For most of American history, the federal government was content to leave the relief of the distress caused by poverty to state and local units of governments or to private welfare organizations. It did not see for itself any more positive a role. Nor did the public expect the federal government to do anything more. Obsessed with the conviction that opportunity beckoned everywhere, and with the idea that poverty was an unavoidable part of civilization and, as taught by those who preached the Gospel of Wealth, the result of individual weakness, the American people were not particularly concerned with the larger problem of poverty. As a result, they did not envision a role for the federal government in combating it. The Depression began to bring about a change in viewpoint, and the administration of Franklin D. Roosevelt proclaimed the national interest in the economic well-being and security of all Americans as a part of its "New Deal." Under that banner, the government cooperated with the states in guaranteeing minimal assistance to impoverished Americans and inaugurated a series of programs providing Americans with a wide range of welfare services. It might well have moved on from concern for the alleviation of distress to concern for removal of the causes of distress if World War II had not so quickly intervened. The war removed the urgency from the problem of poverty, however, and post-war administrations, faced as they were with great problems of adjustment to the post-war world, both at home and abroad, and finding the nation generally prosperous, were not required to make any change in the federal role. The social legislation of the thirties was continued, and in some cases expanded, but there was no pressure for the government to do more. It was not until the administration of John $F$. Kennedy that a general climate favorable to more positive action by government on a broader front was established, and it remained for President Lyndon Johnson to zero in on poverty. President Johnson set the achievement of a "Great Society" as the goal of the American nation and as the first step toward such a society demanded an attack on poverty. Indeed, Johnson saw in a "war on poverty" an opportunity to do something both intrinsically worthwhile and symbolically important to the Great Society he postulated. Thus by 1964 the way was

* A.B. I944, Colorado College; A.M. I949, Ph.D. I95I, Princeton University. Professor of Political Science, Duke University. Author, [with Alpheus T. Mason] IN Quest of Freedom: American Political Thodght and Practice (1959); [with Redding S. Sugg, Jr.] The Administration of Interstate Compacts (1959); [with Robert H. Connery] The Federaz Government and Metropolitan AREas (1960). Contributor to periodicals of articles chiefly in the ficld of American national and state government. 
prepared for the development of an antipoverty program and so finally for a role for the federal government in that endeavor.

It is the purpose of this paper to see how that role was visualized by the President and Congress and how it has developed at the hands of the Office of Economic Opportunity (OEO) since the war on poverty was actually launched. It will be the thesis of the remarks that follow that the federal role was not clearly defined at the outset and that as of Spring 1966 it still remains obscure. Some of the circumstances which may explain that obscurity will be discussed, and a few comments made as to the possible future development of that role. It is obviously too early to expect a final judgment to be made; but if, as it seems likely, a virtual revolution in federal role is in the making, it is important to initiate inquiry and to begin to maintain a careful watch. For more than a drive to eliminate poverty is at stake here; the delicate balance of the federal system may be involved as well.

The President did not declare war on poverty on the spur of the moment. For some while there had been a rising volume of protest at the human and economic waste produced by poverty in the United States and of suggestions as to how to attack and overcome it. Michael Harrington led those who protested from the outside, ${ }^{1}$ and the Council of Economic Advisers led the protests within the government. A large portion of the r 964 report of the Council was devoted to the problem of poverty. The Council concluded its discussion by calling for a "new federally led effort" to get at the problem, which effort, the Council declared, should "marshal already developed resources, focus already expressed concerns" and coordinate the "diverse attacks" on poverty being made by individual communities, state and local governments, private organizations, and federal agencies carrying on programs in such fields as education, health, housing, welfare, and agriculture. ${ }^{2}$ The nation's attack on poverty, the report concluded, "must be based on a change in national attitude. ... It is time ... to allow Government to assume its responsibility for action and leadership in promoting the general welfare."3

Just what the Council visualized as the exact role the federal government ought to play as it assumed that responsibility, it did not say. Nor were others any more helpful. Thus Senator Hubert Humphrey, soon to be Vice President and to be entrusted with overall supervision of the government's poverty effort, believed that "Government alone cannot solve the problem. Political leaders can stimulate goals, make speeches, write books, and introduce legislation, but in the final analysis it is the union of government, private industry, and free labor which gets the job done." Indeed, Senator Humphrey asserted, "federal domination" of such an

${ }^{1}$ Mighael Harrington, The Other AMerica (1962).

2 Council of Economic Advisers, Annual Report 77 (1965).

${ }^{8}$ Id. at 78.

4Hubert H. Humphrey, War on Poverty i5 (x964). 
effort was to be avoided and "joint-venture planning" utilized instead. As his model for the war on poverty, Humphrey used the World Bank, where "politics are kept to an absolute minimum." "The Bank," Humphrey pointed out,

does not initiate projects and keeps hands off local policy. Although the Bank may advise and consult as to desirable projects, and even engage in some promotional activity, all projects and applications are originated locally. The Bank reviews them to make certain that they will make a substantial contribution to local living standards and that they are economically feasible

and it grants funds to those of which it approves. But that is all it does. The federal government could do no better than to follow that pattern, Humphrey seemed to say, in the war on poverty. The federal government would be only a partner, ${ }^{7}$ albeit the moneyed partner, with responsibilities perhaps for planning and coordination but little more. In the last analysis, the program had to be a cooperative one.

Even John Kenneth Galbraith, on whom Democratic policy-makers had leaned for advice and counsel for many years, and whose views President Johnson might as likely have solicited as those of Senator Humphrey, did not offer a much clearer idea of the role he expected the federal government to play in the action on poverty he recommended. As Galbraith saw the problem, it was "the problem of people who for reasons of location, education, health, environment in youth, mental deficiency, or race, are not able to participate effectively-or at all-in the economic life of the nation." These people must be rescued, Galbraith declared, and in their rescue both "a steady expansion in economic output" and a "broad and equitable distribution of services" would be required. But though he went on to speak of "public effort and public funds" being necessarily involved, and called for assumption of such an effort as one of the "needed tasks of government," he did not spell his ideas out any further.

Whether President Johnson in fact did consult either Humphrey or Galbraith is not important. What is important is that they added nothing in their public expressions at least to what the Council of Economic Advisers had had to say about how to wage an effective war on poverty. And no one else seems to have addressed themselves to the question at all. Thus the President does not seem to have had the kind of assistance in formulating his proposals one would ordinarily expect him to have had. At least in his special message to Congress in which he amplified the brief declaration of war on poverty he had made in his State of the Union speech, he did not bring the federal role in the proposed poverty program any more sharply into focus than the others had done.

\footnotetext{
Id. at 36.

Id. at 37 .

TI. ch. $\mathrm{Ir}$.

${ }^{8}$ Galbraith, Let Us Begin: An Invitation to Action on Poverty, Harper's Magazine, March 1964, p. 16.

Id. at $16, \mathrm{I} 8$.
} 
In his message, the President spoke of "men and women throughout the country" preparing plans to attack poverty in their own local communities, and he emphasized that no plans would be "prepared in Washington and imposed upon hundreds of different situations." All plans would instead be "local plans." He went on to declare, however, that he had no intention of letting the war on poverty become "a series of uncoordinated and unrelated efforts," and that, to prevent such an eventuality from occurring, he was establishing in the Executive Office of the President an Office of Economic Opportunity (OEO). He did not go on to say how he expected the Office to work with the hundreds of local communities he visualized making plans, nor did he say anything else which served to give a clue as to what the actual federal role in the war on poverty might be.

It is very probable, of course, that no precise description of the federal role in the projected war on poverty could have been made at that point. The President had, after all, already entrusted the conduct of the war to Sargent Shriver, whom he had designated as Director of the new Office of Economic Opportunity. In developing the Peace Corps, Shriver had been given relatively free rein by the President and Congress; and, despite his obvious disdain for orderly procedures and standard methods of organization, ${ }^{10}$ he had been outstandingly successful. President Johnson would have been very unlikely to have asked Shriver to handle the war on poverty any differently. Nor is there any indication that he did so. Thus the President must have known that by entrusting the antipoverty effort to Shriver, he was to a large extent giving the determination of the federal role in that war over to Shriver as well. From the outset, the federal role in the war on poverty was, in other words, necessarily to be a factor of Shriver's personality and unique methods of operation. To the extent that not every aspect of either his personality or his methods of operation was known, to that extent the federal role in the war on poverty could not be known either.

But if the President had already designated Shriver to head up the antipoverty program and had created the Office of Economic Opportunity to back him up, neither the President nor Shriver probably expected the whole responsibility for defining the federal role to devolve on Shriver. The President had already indicated his own personal interest in the whole program and had evinced a determination to keep his hand in, and he was certainly aware of the role other federal agencies would necessarily have to play in conducting the broad scale attack on poverty he intended to wage. For his part, Shriver had consulted with a wide variety of people in education and civic groups, in business, labor and agriculture, and in state and local government in the process of heading up the task force on poverty for the President; and, in his own words the first day of the hearings on the Economic

\footnotetext{
${ }^{10}$ See Loftus, Aid to Aged Poor Reported Lagging, N.Y. Times, Dec. 22, 1965, p. 15, col. 6, where he speaks of "Shriver's administrative theory of setting up countervailing forces," and Haddad, Mr. Shriver and the Savage Politics of Poverty, Harper's Magazine, Dec. 1965, p. 43, at 45.
} 
Opportunity Act of 1964, he had found "that the leaders of business as well as the leaders of labor and the leaders of voluntary organizations as well as the leaders of local government ... [were] ready to enlist in [the] war against poverty."11 He had found, in other words, a firm determination on the part of those groups to keep the poverty program from becoming completely centralized in Washington. In advising the President, he must have relayed his findings.

In any case, the draft bill authorizing the war on poverty was unique, Shriver was to tell Congress, "in the extent of its reliance on local leadership and initiative." The program being recommended, he went on, "creates a partnership between the Federal Government and the communities of this Nation. It also creates a partnership with business and labor, farm groups, and private institutions."12 However, just as the President had not given any details of how such a cooperative endeavor might be made to function, neither did the draft legislation. This declared it to be "the policy of the United States to eliminate the paradox of poverty in the midst of plenty" and made it the purpose of the legislation to "strengthen, supplement, and coordinate efforts in furtherance of that policy."13 But nothing further was said to relieve the ambiguity of that original declaration. Indeed, the body of the bill only further confused the picture. Thus, the Job Corps and VISTA (titles one and six) were offered as wholly federal programs. The Community Action Program (part A of title two), admittedly the heart of the proposal, was, on the other hand, proposed as partly local and partly federal, while the Adult Basic Education program (part $B$ of title two) was to be based on state plans and to be administered by state educational agencies. Still other aspects of the program involved direct aid to individuals (titles three and four). And even with regard to those parts of the program involving the federal government, the proposed act did not vest the development of the federal role in the Office of Economic Opportunity alone. Rather, it assigned a variety of roles to a variety of federal officers and agencies. Thus the Job Corps and VISTA were left pretty much up to the Director of OEO to develop and administer, as was the development of the guidelines for federal funding of community action programs. But a number of other federal units were also given responsibilities:

- the U.S. Civil Service Commission was charged by section 107 with enforcing the ban on political discrimination placed on Job Corps enrollees

-the Secretary of Agriculture was empowered to activate part $D$ of title three (indemnity payments to dairy farmers)

- the definitions set by the Farmers Home Administration were to be adhered to in the program of grants to farmers

\footnotetext{
${ }^{11}$ Hearings on H.R. Io44o Before the Subcommittee on the War on Poverty of the House Committee on Education and Labor, 88th Cong., 2d Sess., pt. I, at 20 (1964).

12 Id. at 21 .

${ }^{13}$ S. 2642, 88th Cong., 2d Sess. (1964). The administration bill was subsequently incorporated into the statute. Economic Opportunity Act of $1964, \S 2,78$ Stat. 508, 42 U.S.C. $\$ 2701$ (I964).
} 
-the Small Business Administration was entrusted with operating title four of the act

-the Secretary of the Treasury was obligated to set the rate of interest to be charged on loans under part A of title three and section 404

-the Secretary of Health, Education and Welfare was charged with executing the agreements with the states in the Adult Basic Education Program and with conducting the Work Experience Program under title five.

-the President was authorized not only to appoint the Director of OEO and his chief assistants but to fix their salaries, move the OEO itself out of the Executive Office of the President, appoint members to the National Advisory Council, and direct other federal agencies to cooperate with OEO.

Last, but far from least, Congress itself was given a part to play in the program. Not only was it placed in the position of imposing conditions upon several of the programs and limiting the power of the Director in a number of ways; in one area it was even given the chance to make it clear what the federal role was not to be. In both sections 205 and 6r4, the proposed legislation provided that no grant or contract authorized under the terms of the act might provide for general aid to elementary or secondary education in any school or school system. But beyond that, the draft legislation was not descriptive of the actual role to be played by the federal government in the war against poverty.

Thus, when Congress began to hold hearings on the proposed legislation in March 1964 , it had an unusual opportunity to clarify matters. Unfortunately, it did not seize that opportunity. Although special subcommittees of both the House Committee on Education and Labor and the Senate Committee on Labor and Public Welfare held hearings (those in the House at considerably more length than those in the Senate), and as a result of those hearings, a good many changes were made in the administration bill, the matter of federal role was not raised by the majority of the witnesses and was given virtually no attention in the majority reports. Thus, for example, Senate Report No. r218 merely repeated the same kind of language already used to describe operations under the act: "Each of the ... programs authorized by this bill," it declared, "will contribute to and reinforce the efforts of the community to strike at poverty at its source." It was to be the "special function" of the Director of the Office of Economic Opportunity "to coordinate the programs authorized under this bill, to see that these programs, and other Federal programs related to the war on poverty augment and reinforce the efforts of the individual communities in the war on poverty."14 Only a few minority members questioned the legislation in terms of federal role. Representative Peter Frelinghuysen (R., N.J.) pointed out that the bill ${ }^{15}$

charts a new and unjustified course for governmental responsibility in general and for the Federal role in particular. It proposes a Federal bureaucracy whose in-

\footnotetext{
${ }^{14}$ S. REP. No. r2r8, 88th Cong., $2 d$ Sess. 7 (1964). (Emphasis added.)

${ }^{10}$ Id. at $8 \mathrm{r}$.
} 
fluence would permeate every nook and cranny of civic responsibility-public and private.

I cannot conceive of such intervention being in the best interest of liberal democratic institutions.

On the Senate side, Senators Goldwater and Tower observed that "the administration has determined, apparently, that Federal intrusion into State and local matters must be complete and untrammelled where the political and sociological imperatives of the war on poverty are involved."16 How much better, thought Senator Javits, it would have been if the federal government had declared a joint war "with the States and local governments" instead of a federal war alone. ${ }^{17}$ In committee and in floor debate, the Republican and Southern Democratic opposition to the bill hit over and over again at the problem the legislation posed for traditional federalism and specifically for state and local autonomy and at the danger of having the program's legitimate goals frustrated by the bureaucratic confusion and overlapping which was built into the proposal before them. In the end, however, the bill was passed pretty much as it was submitted. The only change bearing on the federal role which the minority was able to introduce successfully was the provision for a gubernatorial veto of the location of Job Corps centers and the stationing of VISTA volunteers within the confines of a state. For the rest the blurred picture of the federal role was not much improved. The House Committee on Education and Labor, indeed, emphasized in its report that the legislation did not originate or pass as a wholly federal program; rather, it noted that "As a nation, we clearly have the capacity to achieve . . . victory [over poverty]; what we need now is a commitment on the part of the people, the communities, private organizations, and all levels of government."18 Passage of the bill constituted such a commitment and made possible a plan of action in which "the Federal Government will work cooperatively with the local and State governments so that the treasured local-State-Federal partnership may be maintained."10 Particularly with regard to the community action part of the program was the cooperative nature of the antipoverty enterprise stressed. Community action programs were based, the Committee declared, "on the belief that local citizens know and understand their communities best and that they will be the ones to seize the initiative and provide sustained, vigorous leadership." They are based, too, the Committee went on, ${ }^{20}$

on the conviction that communities will commit their ideas and resources and assume responsibility for developing and carrying out local action programs. Thus, the role of the Federal Government will be to give counsel and help, when requested, and to make available substantial assistance in meeting the costs of those programs.

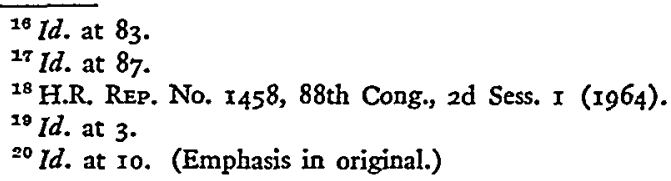


Thus, as matters stood when the Economic Opportunity Act of 1964 was passed, a vast program had been authorized and hundreds of millions of dollars appropriated to get it started, but no clear picture of the role the federal government was to play in its development and operation had been drawn. It was obviously an action program and a cooperative one, one in which there were at least three partnersthe federal, state, and local governments-if not more than that, if the references in all the discussion leading up to the passage of the act to labor, business, agriculture and private organizations meant anything at all. Funding by the terms of the act was to be up to ninety per cent provided by the federal government, and the Office of Economic Opportunity was given a great deal of discretion with regard to making grants. But it appeared that, in essence, the federal role was at most a complementary one to the primary efforts of states, and particularly of local governments, to wage war on poverty at home and that in fact it was neither a departure from existing roles nor a very large one at that.

\section{III}

Before turning to an examination of how the federal role in the poverty program has evolved since the program has been in operation, a few comments are in order. Although it will probably never be known precisely why the federal role in the antipoverty program was left so poorly defined, it may be that there are one or more general explanations for the fact. In a way the war on poverty was the product of a particular moment of time. It marked the end of the Johnson administration as a caretaker of the Kennedy program and provided the bridge to the development of a peculiarly Johnson program. As such, it was important to get it into early and dramatic operation. Something else might have been chosen for the occasion, but the fact is that nothing else was. Thus the war on poverty was in a sense in the position of an actor who is thrust onto the stage before he has learned his part or even found out who else is in the play. Only a little more time might have served both the actor and the poverty program in good stead.

It may also be that very little thought was given to the role the federal government should play in the program. Certainly there is evidence in other respects that the program was advanced hurriedly and without the careful planning which might have been expended on it. The entire program, Robert Theobald observed, reflected a dire "lack of research." "We don't know enough; we have not done enough research; we are flying blind," he complained ${ }^{21}$ - a conclusion with which a number of other observers agreed. ${ }^{22}$ Had the program awaited the conduct of further research, some of it might have gone into the question of federal role.

\footnotetext{
21 Theobald, Johnson's War on Poverty, New Politics, Fall I964, p. I4, at 23-24.

22 See, e.g., Hechinger, Head Start to Where?, Saturday Rev., Dec. 18, 1965, p. 59, with regard to Project Head Start; Cope, It's What's Happening, Baby, i9 National Rev. 930-32 (I965) with regard to the Job Corps.
} 
There is probably some substance in the suggestion, too, that the poverty pro gram was launched as an article of faith. As a recent Time essay commented, it reflected "the uniquely American belief ... that evangelism, money and organization can lick just about anything, including conditions that the world has always considered inevitable."23 The whole program, Paul Jacobs concluded, was based on "an almost mystical belief in the infinite potentials of American society. Poverty, like polio, will be defeated when the right vaccine is found."24 In such a rarified atmosphere as this, consideration of such a thing as the role of the federal government seems unnecessary, if not actually somehow subversive.

Moreover, it should not be overlooked that the war on poverty was declared in 1964 , an election year, and despite the broad support for it in every quarter, the fact of its timing inevitably had political overtones. The whole question was dealt with along political lines in Congress, and both political parties and candidates in the presidential election were glad to get whatever mileage they could out of it. In political debates there is often a great deal of smoke, but just as often too little heat to succeed in refining the metal.

Or the failure to enunciate clearly the federal role in the poverty program may have resulted from the belief of those responsible for its development that there was little to be gained by stating the obvious. Through a number of welfare programs, some of them thirty years old already, the federal government had already begun to play a role in the nation's fight against poverty. To the extent that the expanded war on poverty has built upon and utilized these older programs, it may have seemed that no new role at all was involved, but merely an extension of an existing -and by $\mathrm{i} 964$ presumably a familiar-one. Thus no detailed analysis seemed to be necessary then.

Finally, it should be noted that it is always and in every case futile to expect the federal role in any area of activity to emerge in sharp and perfectly clear focus. The very nature of the American system of government prevents it. Not only is the federal role always determined to some extent by the nature of each separate program's leadership (thus the poverty program, as noted above, was foreordained to be a product of Shriver's ability and enthusiasm), by the nature of the times and the climate of opinion which prevails when it is undertaken (the economic boom was the largest thing in sight in mid-rg64 and the war in Viet Nam had not begun to escalate), but that role is also and always divided, even as the American system of government itself is divided, between several units in the two houses of Congress, between Congress and the executive branch, and between a number of units in the executive branch, as well as in many cases between the federal government and the states and their subordinate units. In every program every year, there is always concern to see that that program is visualized the same way in both houses of

${ }^{23}$ The Poor Amidst Prosperity, Time, Oct. I, 1965, p. 34.

${ }^{25}$ Jacobs, America's Schizophrenic View of the Poor, $20 x$ Nation I91, 196 (1965). 
Congress, that the executive unit charged with its administration carries it out the way Congress intended, and that there is the desirable degree of coordination of effort between the several units in the executive branch concerned with its execution. And it should never be forgotten that the federal role in many programs is a direct product of the strength and vigor of state and local governments. In areas where the latter are strong and active, as they are in education, for example, the federal role is usually less. Where state and local governments on the other hand are weak or have acted irresponsibly or not at all, or are divided among themselves, the federal role can be expected to be much larger. Certainly a case can be made for the fact that the states had not distinguished themselves in the poverty area prior to $x 964$.

It is of course idle to speculate on which, if any, of the factors just discussed were operative when the poverty program came into being. In any case, it is not necessary because the program has been in operation long enough now to give some idea of what the federal role is in fact, even if what it was intended to be remains obscure. Even so, however, it is still probably not possible to see that role as it may finally turn out to be. For one thing, twenty months is far too short a period of time to permit anything like final judgment to be rendered; for another, there is some evidence that so far the public has only been allowed to see what OEO press agents have wanted it to see; ${ }^{25}$ and finally it is always true that a role at the outset of an enterprise may very likely change as the program settles down into routine.

This latter point may be particularly pertinent with regard to the poverty program, if the judgment of two careful observers is correct. It was their considered opinion that at least by September 1965 only "verbal solutions" had been reached to the problems of poverty "at the federal level" and that it was by then "quite apparent that the ease of conceptualizing anti-poverty programs at the federal level had just about been matched by the difficulty of translating these into meaningful operative actions at the local level."28 The full impact of the antipoverty program has as of this writing thus yet to be felt, and as a result no last word can be written about the federal role therein.

Certainly the chief conclusion which can be drawn from the evidence on the poverty program so far available is that it is having a profound effect on local government in the United States. That effect is not so evident in connection with the

\footnotetext{
${ }^{25}$ See Hechinger, supra note 22 , at 58 , who is convinced that the war on poverty has been the object of an "official oversell" from the beginning; see also Haddad, stipra note 10, at 45, who recognizes the fact that Shriver "uses the levers of power with one eye on the press."

${ }^{20}$ Bensman \& Tobier, Anti-Poverty Programming: A Proposal, Urban Affairs Quarterly, Sept. 1965, pp. 54-55. Their conclusion was supported a little later by a writer for the Associated Press, who wrote on Nov. 28, 1965, that the poverty program was only then "beginning to emerge from the planning stage." Price, War Against Poverty Is Now a Light Skirmish, Durham Morning Herald, Nov. 28, 1965, $\$$ D, p. x.
} 
Job Corps and VISTA, or any of the other programs under the several titles of the act, as it is in connection with the community action programs. There OEO in general and the Director, Sargent Shriver, in particular, have asserted themselves positively and in so doing have begun the development of a role for the federal government which was not only not specifically called for by the Economic Opportunity Act but one which in the long run may be the most significant aspect of the poverty program. At Shriver's original suggestion, while he was serving as head of the task force developing plans to recommend to the President for the war on poverty, the act requires the "maximum feasible participation of the residents of the areas and the members of the groups served"26n by the community action programs-that is, the poor themselves. The act, however, did not go on to define what was meant by the phrase, with the result that in practice it has been defined by the OEO and especially by Shriver. As so defined, it has cast the federal government in a role it has never before played so directly, for, in effect, enforcing that requirement of the act, as interpreted by OEO, has involved the federal government in nothing less than reshaping American local government. As Richard Cloward put it, "the involvement of the poor is precisely [a question] of power and its redistribution." 27 Where resistance to that involvement by local politicians has been encountered-and it has been quite frequently-the role of the OEO and thus of the federal government has been one of forcing local political organizations to alter their traditional patterns of operation and admit representatives of the poor to their poverty councils. As Shriver himself put it, ${ }^{28}$

Before we grant one cent, we require the involvement of the whole community in the planning and operation of the program. We specify representation of the poor. In effect, we are asking those who hold power in the community to "move over" and share that power with those who are to be helped. We insist that this can't be just a token involvement. It must be a real one.

Not only are the poor to be involved, but Negroes and other minority groups as well. Shriver has made it clear that OEO regards it as part of the federal function in the community action part of the war on poverty to force integration on local community action groups. Indeed, he declared, no community action program would be funded unless it contributed to "undermining the barriers of discrimination."29 And in several instances, OEO has declined to fund until integrated community councils were evolved.

"The war on poverty," Shriver told the House Committee on Education and Labor in April 1965 , "is not just aimed at individuals. ... It is an attempt to change institutions as well as people." It is concerned with "hostile or uncaring or ex-

\footnotetext{
${ }^{262}$ Sec. $202(a)(3), 78$ Stat. 516,42 U.S.C. $\$ 2782$ (a) (3) (1964).

${ }^{27}$ Cloward, The War on Poverty-Are the Poor Left Out?, 201 Nation 55, 58 (1965).

${ }^{28}$ Shriver, How Goes the War on Poverty?, Look, July 27, 1965, p. 33.

20 Id. at 34 .
} 
ploitive institutions," whether they are governmental or private, ${ }^{30}$ and especially with the traditional institutions of local government, which for many years had ignored "the views of the poor themselves or of representative community groups." place of such institutions, Shriver once commented, he hoped to see "a forwardlooking mayor, interested in serving all the people, responsive to the needs of the electorate... [providing] democratic leadership" to the whole community. ${ }^{32}$ The community action program, Shriver concluded, was the special tool of the federal government to bring such changes about. The community action program, he observed, is a program ${ }^{33}$

where an entire city, or neighborhood, or county, or State enters into a binding agreement to pull itself up by its bootstraps. In effect, it means that communities are applying to us for a new type of corporate charter. They are incorporating themselves as a new enterprise-a new business-the business of creating opportunity for the very poor.

When a community applies to OEO for funding, and OEO makes a grant, the charter of which Shriver speaks is issued. Through the conditions OEO sets as a requirement for funding, in other words, it achieves its objectives at the local level.

Again and again, communities throughout the country have been denied funds until they clearly established their willingness to give representation to the poor and minorities. Sometimes, the action was widely publicized; other times, it was not. ... If the politicians frustrate local efforts for poverty planning, we will withhold or withdraw federal funds. We have followed this hard line from the first days of the program, and have no intention of abandoning it now. ${ }^{34}$

Funding can also be used positively to accomplish the same objectives. Thus, in at least one instance OEO awarded money to a local effort to educate and arouse the poor so as to be better able to participate effectively in local antipoverty councils. Part of the grant to the Community Action Training Center at Syracuse University was to be expended on training the poor to organize to achieve power in the community. The professional organizer, Saul Alinsky, was employed for a while by the Center as a consultant and lecturer in the program. As Shriver wrote to Representative Adam Clayton Powell (D., N.Y.) on May I2, I965, OEO "can condition the funding of a particular application or of future programs upon the more effective utilization of resources, upon the inclusion of programs not applied for, or upon the use of agencies whose proffers of service have not been accepted."35 For

\footnotetext{
${ }^{30}$ Hearings on Examination of the War on Poverty Program Before the Subcommittee on the War on Poverty Program of the House Committee on Education and Labor, 89th Cong., Ist Sess. I6-17 (1965) (opening statement of Sargent Shriver).

${ }^{31}$ I Office of Economic Opportunity, Congressional Presentation 83 (I965).

${ }^{32}$ Shriver, supra note 28 , at 33.

${ }^{33}$ Hearings, supra note 30 , at 17 (opening statement of Sargent Shriver). (Emphasis added.)

"Shriver, supra note 28 , at $33-34$.

${ }^{35}$ Letter from Sargent Shriver to Adam Clayton Powell, in Hearings, supra note 30 , at 78 .
} 
what the community action program is all about is social change. As Senator Winston Prouty (R., Vt.) has pointed out, the poverty program "involve[s] a mobilization of local people and a restructuring of socio-economic patterns, which must necessarily put a certain amount of strain on the social fabric."36 If the war on poverty is to succeed, Shriver has determined that OEO can do little else but use its power to fund so as to produce the changes it deems to be required. Even if doing so involves OEO-"the federal government"-in "a ruthless struggle for power" with officials of local government, so be it. For experience has already taught $O E O$ that it "cannot aristocratically rise above politics and hope for the best. It must [instead] enter the struggle and win the battle."37

It could be-and it has often been the case-that OEO decides the battle can be won in a particular community only by avoiding the local government unit altogether. The act permits the Director to pick whatever agency or agencies, public or private, seem to him most appropriate to accomplish the program's objectives in each community. The choice is essentially an ad hoc one, made on the basis of the peculiar circumstances of each community. "We are trying to create at the local level," Shriver told the House Subcommittee on the war on poverty program, "to the extent that we can, a . . . unit which will bring all the resources of the community to bear on poverty ...."38 Public officials "are not the only representatives who have an interest in combatting poverty," Shriver has declared. Other groups may quite as legitimately be entrusted with the conduct of the local antipoverty effort if they have a more "intelligent program" to offer. ${ }^{30}$ In a number of cases, in recognition of this possibility, OEO has awarded grants to such a group over the competing claims of the traditional unit of local government. It has not done so without objection, ${ }^{40}$ but it "has used [its authority] ... sparingly and reluctantly in the absence of more forceful guidance from Congress" on the matter. ${ }^{41}$ To the extent that such nongovernmental agencies are chosen, important questions of responsibility and accountability are raised for answer.

One other impact of OEO on local government might be mentioned, although it seems to be more a potential than a realized fact. It would appear that in its ability to choose which agencies shall carry on community action programs OEO has an opportunity to bring about real change in the governmental structure of the nation's metropolitan areas. Shriver has declared repeatedly that OEO's general policy is to permit "maximum flexibility to local community action organizations"

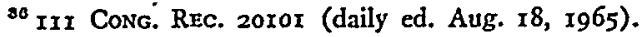

${ }^{87}$ Haddad, stepra note to, at 50.

${ }^{88}$ Hearings, supra note 30 , at $4 \mathrm{I}$.

so Id. at 54 .

${ }^{10} \mathrm{Sec}$ the complaint of Representative Albert Quie (R., Minn.), one of the most outspoken critics of the war on poverty, to his colleagues in the House that a citizens committec might be selected to run a poverty program in his district instead of the county commissioners. 111 Conc. REc. I6955 (daily ed. July $2 \dot{\mathbf{r}}, \mathbf{1 9 6 5 )}$.

NI.Y. Times, Aug. 20, 1965, p. x, col. 4 .
} 
and that under that policy it will permit agencies to establish a program "for a city, an entire metropolitan area, a number of cities plus adjoining rural areas, and a variety of other political and geographic configurations." In no instance has OEO yet required "an amalgamation of geographic or political areas into one community action program." But it will not hesitate to do so, Shriver assured Representative Powell, in "those cases where there is a clear showing that the local plan is unwise, uneconomic, or unfairly discriminates against adjacent areas or communities." T2 Thus, it may be possible for OEO to launch an attack on the governmental fragmentation which has been the greatest stumbling block in the way of progress in solving the nation's metropolitan area problems. If it begins to exert pressure to force community action programs to embrace entire areas, it might not take long for the other functions of government at the local level to begin to follow suit. The long term impact of this kind of pressure might thus be the most important contribution the war on poverty could make to American life. For it is widely held that the nation's urban problems will continue to defy solution until those problems are dealt with on a unified basis. If OEO were to lead the way, it would reach into the very center of American local government.

It is not only through making grants originally, however, that OEO exerts influence on local government and so brings the federal government into a new relationship therewith. Both in monitoring the operation of local programs and in considering applications for the renewal of grants when they begin to run out, OEO will have additional opportunities to make the presence of the federal government felt in local affairs. Although it is too early yet for renewal applications to have begun to come in in any quantity, OEO has already started to supervise program operations to assure that the program as projected in the original application is in fact being carried out. Funds to both HARYOU-ACT, the controversial antipoverty program in Harlem, and the antipoverty program in Boston were cut off in rg65 while OEO made an investigation of charges of mismanagement. To handle such investigations, OEO has created an Inspections Office, composed, in Shriver's words, "of persons who are knowledgeable about poverty" and who give him directly "their independent evaluations of what ... others are doing or saying they are doing, using our money. So we have had fairly good intelligence so far about the various community action programs .... and whether we are getting our money's worth and whether somebody is trying to gyp us someplace or other." 33 In addition to suspension of funds, publicity can be used to bring erring local agencies back into line. While these tools are not unique to the poverty program, and indeed are available to most other federal agencies responsible for administering grant-in-aid programs, in combination with other powers OEO has over local governments they take on greater significance.

\footnotetext{
${ }^{10}$ Hearings, supra note 30 , at 78 . (Emphasis added.)

${ }^{18}$ Id. at 69 .
} 
Despite the undeniable power OEO possesses to induce change at the local level of government, it ought in all fairness to be noted that the OEO guidelines for the community action programs were not drawn up arbitrarily and imposed by fiat. On the contrary, the community action program guidelines were drawn up with the advice of local representatives called especially to attend at least two meetings to discuss them. Moreover, the exercise of OEO discretion in applying the guidelines can only take place after a local agency has submitted an application. Like a court, OEO cannot act until someone else brings a case before it. It lacks altogether the power to initiate action on its own. ${ }^{44}$ Finally, despite a number of instances of alleged-and probably actual-interference with local program operations, the published records of OEO give no indication that interference has been general or that it has become the standard practice of the Office in relation to local antipoverty efforts. Quite the contrary. Community action programs, once established, are not regarded as parts or adjuncts of OEO. The record shows that OEO has extended wide latitude both in original program design and in program operation to local agencies and has not unduly overridden local authority. Indeed, that the federal hand has not yet been overly oppressive is suggested by William Haddad, who noted that "Though the War on Poverty can chalk up many victories in the cities and the more industrialized areas, it is stalemated in some rural counties of the South-notably in Appalachia, where the local politicians could teach big-city bosses a trick or two." Unless OEO "can somehow change this pattern," of absolute boss control over local affairs, there is no real possibility that those areas can benefit from the poverty program-or indeed that a larger federal role will actually develop there-at all. ${ }^{45}$

The impact of the federal government on local government is without doubt the most important effect the antipoverty program has had in operation. It should be noted, however, that the program may be having a negative impact on the states as well. For although a gubernatorial veto was inserted into the act at the last moment, and though OEO has granted some funds to states for their own use in coordinating local antipoverty programs, by and large the whole war on poverty ignores the states and establishes the most direct and powerful connections between Washington and the thousands of city halls and county courthouses in the nation that have ever been developed. The implications of such connections are hard to describe at this stage, but the very vigor with which the states have insisted on some sort of a role in the antipoverty effort attests to their concern about the matter.

\section{$\mathrm{V}$}

Although the potentiality of an alteration in the federal system seems to be the

\footnotetext{
4 The act does permit (Economic Opportunity Act of $1964, \$ 207,78$ Stat. 518, 42 U.S.C. $\$ 2787$ (1964)) the Office of Economic Opportunity to make demonstration grants, and in the development of these grants the Office may be active from the beginning.

${ }^{\circ}$ Haddad, supra note ro, at 48.
} 
most obvious lesson to be learned from a year or more of operation under the poverty program, other developments have taken place which may be significant as well. Most of the remarks in the preceding sections have spoken of the federal role as if it were one. In fact, as noted above, it began divided; and in operation it has, if anything, become even more so. The Director has, as predicted, emerged as the dominant figure in the war on poverty-so much so that in journalese he was dubbed the "poverty czar" and that appellation has stuck. There is not an aspect of the entire program that has not felt his influence; and presumably now that he is free to devote full time to conducting the war on poverty, it will be cast even more closely in his image. Even so, the Director and OEO are not synonymous. The Community Action Program is under the immediate supervision of T. M. Berry, a Negro, with whom Shriver has been reportedly at increasing odds. Once having been appointed, however, he cannot now for obvious reasons be easily removed. Moreover, pressures from Congress and constituents, as well as from state and local leaders, forced the decentralization of OEO before it had been functioning very long. There are now regional offices in New York, the District of Columbia, Atlanta, Chicago, Kansas City, Missouri, Austin, and San Francisco, which serve to dilute both the Director's power and the unity of OEO still further. And outside of OEO, Vice President Humphrey has evidently played a role of some importance in the antipoverty effort which has not always coincided with Shriver's own wishes. Designated by President Johnson to oversee the administration's entire antipoverty program, it was Humphrey who brought an end to "interagency squabbling" in the early days of the program, ${ }^{46}$ and even as late as early December 1965, newspaper reports cast Humphrey in the role of chastiser of Shriver in behalf of the President, who was reported to be anxious both to keep peace in his political family and retain the services of Shriver in the war on poverty. ${ }^{47}$ The President himself has retained his interest in the program, as evidenced most recently by his State of the Union address. If he has not personally become involved in its operation, he has evidently made use of the Budget Bureau as his staff arm to do so. At least, in the fall of I965, widely circulated reports had it that the Bureau had "allegedly 'suggested' that Mr. Shriver stop emphasizing the participation of the poor in policy-making." 48 As the editors of America remarked, "Just what did happen remains obscure,"49 but there is no reason to suppose that the Budget Bureau has less power over programs administered by the OEO than it does over those entrusted to other federal agencieswhich power is enough to make it a force to be reckoned with in OEO operations. Finally, a number of other federal agencies than those originally involved in the poverty effort have come to have a role to play, thus further fractionalizing the

\footnotetext{
${ }^{10}$ Life, March 26, 1965, p. 42.

${ }^{4}$ See, e.g., Evans \& Novak, Tensions in Anti-Poverty War Show Up, Durham Morning Herald, Dec. $3,1965, \S$ A, p. 4 .

1 I3 America 74I (1965); see also N.Y. Times, Nov. 5, 1965, p. r, col. 5.

60 II3 AMERICA 74I (1965).
} 
over-all federal role. The Department of Interior through the loan of departmental officers to run Job Corps centers, the U.S. Employment Service through its role in selecting Job Corpsmen, and the National Institute of Mental Health and the Public Health Service with regard to community action program grants involving community health centers and environmental health projects, have all been added to the roster.

Congress has continued to claim part of the role as well. The chairman of the House Committee on Education and Labor and the Chairman of that Committee's subcommittee on the war on poverty program sent out task forces to investigate alleged problems in OEO administration in late March and held a series of hearings in April r965; the Senate Appropriations Committee, under the prodding of Senator John Stennis (D., Miss.), looked into Project Head Start; ${ }^{50}$ and the Senate Committee on Labor and Public Welfare looked into "a number of problems involved in administration of the act by the Office of Economic Opportunity" on its own." The upshot of the several investigations was basic approval of OEO's conduct of the war. No fundamental changes were made in the program, and the amount authorized to be expended on it in fiscal rg66 was nearly doubled. Even though Congress was thus demonstrably satisfied with the over-all program, it acted in several ways to tighten up the administration of the community action part of the program. In so doing, it went a little way toward clarifying in law the role it visualized for the federal government in the program. Thus, it noted the criticism that information about the poverty program had not been easily available and through the report of the Senate Committee on Labor and Public Welfare declared its expectation that OEO would "undertake, pursuant to its coordinating obligation under section 6II of the act, to establish a procedure for assembling such information so that public information may be complete and readily available."52 Further to that end, the act itself was amended to require OEO to provide "reasonable opportunity" for public hearings to be held on proposed programs. ${ }^{53}$ In response to requests from state officials, the act was amended so as to provide for continuing consultation with state agencies in the development, conduct, and administration of community action programs $^{54}$ and to require the Director to notify governors of the receipt of an application for a community action program from a private agency in a community where a public agency is carrying on a program. ${ }^{55}$ On the other hand, the use of the gubernatorial veto was weakened by an amendment giving the Director

\footnotetext{
${ }^{50}$ N.Y. Times, Nov. 2, 1965, p. 19, col. I.

${ }^{6}$ S. REP. No. 599, 89th Cong., Ist Sess. 6 (1965).

${ }^{52}$ Id. at 7.

${ }^{63}$ Economic Opportunity Amendments of 1965 , $\$$ II, 79 Stat. 975, 42 U.S.C.A. $\$ 2782$ (Supp. 1965).

56 Economic Opportunity Amendments of $1965, \S 1_{5}, 79$ Stat. 976, 42 U.S.C.A. $\$ 2789$ (a) (Supp. $1965)$.

${ }_{55}$ Economic Opportunity Amendments of $1965, \S 17,79$ Stat. 976, 42 U.S.C.A. $\$ 2789$ (d) (Supp. I965).
} 
power to override a veto if he finds a proposed program after all to be "fully consistent with the provisions and in furtherance of the purposes" of the law. ${ }^{56}$

Thus, if the federal role as it may be exercised by the Director is strengthened, the whole picture was further confused by the apparently more intimate involvement of the states. The probability is, however, that concessions to gubernatorial complaints were politic and that appearances may well turn out to be deceiving, the federal role being left indeed stronger and more dominant than it was before. However, Congress did not change the basic idea of local initiative in the community action part of the program, so that the federal-local axis is still there. Congress can be counted on to continue to watch as that axis is used in the months and years ahead and may find it necessary to make corrections in behalf of local governments, even as it already has in behalf of the states. In any case, Congress gives no indication of considering the matter closed.

Nor does the Republican Party. The whole question of the federal role in the poverty program remains very much a political issue and promises to continue so for some time. The Democratic Party has made the elimination of poverty an article of faith and has pledged its efforts toward making sure that the federal government does whatever is necessary to win the war against it. While the Republicans can hardly-and, indeed, have not-come out against the objective of the war, they have been increasingly astringent in their remarks about how the war is being waged. The Republican Party platform of 1964 contained a plank condemning the antipoverty program as overlapping with and contradictory to "the 42 existing Federal poverty programs" and charging that the program would "dangerously centralize Federal controls. ..." A number of Republican members of Congress have continued to keep a sharp eye on the program in operation, as the hearings on the Economic Opportunity Amendments of 1965 attest. By early 1966 , it had become obvious that the issue of federal role would be a major one in the 1966 congressional elections. Already the Republicans are planning to make a demand for increased involvement of the poor in community action programs in an attempt to embarrass the Democrats in the traditionally Democratic big cities, where the Republican Party has not fared well recently. On the first day of the second session of the Eightyninth Congress, Representative Charles Goodell (R., N.Y.) made a statement on behalf of himself and Representative Albert Quie (R., Minn.), the ranking minority member of the House ad hoc subcommittee on the war on poverty program, in which they proposed that Congress strip OEO of all its responsibilities except that for community action programs and that it immediately require one-third of the members of the board of every local community action agency to be from the poor themselves. "This will place them on an equal level with local [read Democratic] officials and social welfare agencies who now dominate the poverty program to the

\footnotetext{
${ }^{56}$ Economic Opportunity Amendments of $1965, \S 16,79$ Stat. 976, 42 U.S.C.A. $\$ 2789$ (c) (Supp. 1965).
} 
point of suffocation. ... [This would] offer hope that the poor can get some of the money now siphoned off into political [read Democratic] machines." Moreover, the two Republicans added, "A properly representative community action board can exercise truly local control of community action programs without constant intrusions by administrators from Washington." challenges the Republicans to exploit the potential of this approach, and it would appear to be a challenge the Democrats cannot fail to meet, especially in the light of President Johnson's pledge to support the war on poverty as it now operates-a pledge renewed both in his State of the Union address and in the remarks he made a few days later when relieving Sargent Shriver of his Peace Corps assignment so that he could devote full time to the antipoverty effort.

Whatever the outcome of the political battle over the conduct of the war on poverty, it would seem to be a necessary conclusion from even a cursory study of the problem it is attacking that, if the war is finally to be won, the federal role in both its planning and its execution can only grow larger and more powerful in the years ahead. For it has become obvious that the successful termination of the war will require the federal government to take an increasingly active role in the national economy and the nation's social arrangements. Thus, part of the program is job training; it will ultimately be necessary to develop the economy so that jobs are available for those who have been trained. While much of the burden in this connection must be borne by the private sector of the economy, the federal government cannot avoid a major share of the responsibility, both because of its own dominant position in the economy and because of its duty under the terms of the Employment Act of 1946 and subsequent legislation. Moreover, as Bem Price has pointed out, "the poor must acquire a social and economic mobility they do not now possess." ${ }^{\text {"s }}$

Part of the responsibility for making that acquisition possible must be accepted by individuals and groups, quite apart from governmental action and coercion. However, to the extent that acquiring such mobility depends on education, it need not be emphasized here to what a large degree the federal government is already involved in the funding of education or how much more federal aid will be necessary for an expanded educational program. The same thing can be said with regard to those parts of the antipoverty effort aimed at improving health, housing, and family life. In all of these a deep federal involvement is required. Moreover, as Mark R. Arnold wrote recently in The National Observer, the poverty program's concern with removing

poverty's causes ... raises serious questions about the role of Government in ending it. Americans traditionally have viewed the poor as victims of forces beyond the control of society. ... But increasingly it is being argued that, in a

\footnotetext{
${ }^{57}$ I12 Cong. Rec. 34 (daily ed. Jan. Io, 1966).

${ }^{88}$ Price, supra note 26.
} 
sense, the poor are maintained in a position of subservience by society itself. Discrimination in housing and employment keeps minority groups in the slums and out of good jobs.

Thus, it is argued, it is not enough to change the poor by teaching them new skills and improving their education. The poverty program must also work to change society-to [give the poor what is] needed to move up to the middle class. ${ }^{.9}$

To do what is necessary to bring that about can hardly help but force the federal government to become a far more active participant in the antipoverty battle than it has been so far. As Arnold concludes, to raise "the expectations of the poor and not provid[e] the means of fulfilling them ... [might] serve to provoke the very disruptions [the antipoverty effort] was intended to avert." ${ }^{00}$ To provide those means, the federal government cannot rely solely on the "public relations approach," as Psychologist Kenneth Clark, who has played an instrumental role from the beginning in developing the war on poverty, has observed. What is needed, he declared, is a "tough-minded and independent ... no damned foolishness approach."61 Utilization of such an approach, needless to say, would considerably expand the traditional federal role vis-à-vis the solution of domestic problems and even add a new dimension to the newer federal role which has begun to develop under the Economic Opportunity Act of I964. Success in this endeavor could well take a generation or more. The problem of identifying the federal role may thus be a continuing one facing students and practitioners of American government.

Finally, it may be that the development of the federal role in the war on poverty will be hinged directly to the federal government's decision as to how to proceed in the crusade for civil rights. Certainly, the antipoverty drive and the drive to extend civil rights are closely intertwined, since a substantial portion of the thirty-five million Americans deemed to be poor are Negro. Civil rights leaders have already mounted a campaign against $O E O$ to obtain faster and more adequate action against poverty, and if the pressure mounts and the administration continues to support the cause, OEO may find it hard to balance its long-term objectives with the shortterm necessity of averting racial strife. In such a contest, it is obvious which alternative would have to be chosen; and what effect such a choice would have on the over-all poverty program can only be conjectured. In all probability, however, it would have a profound effect.

VI

The war on poverty is a going concern. Despite criticisms of details, there is growing recognition of its effectiveness. President Johnson has pledged that it will

\footnotetext{
${ }^{\circ}$ Arnold, A Balance Sheet on Mr. Shriver and His Program: Why 1966 Will Be a Crucial Year in the War on Poverty, The National Observer, Dec. 20, 1965, p. 7.

${ }^{\circ}$ Ibid.

${ }^{21}$ Quoted in Price, supra note 26.
} 
continue to be supported to the maximum extent possible, Viet Nam notwithstanding. Thus it can be expected to become a semi-permanent feature of the American scene. As such, it will make demands on the federal government and, in turn, contribute to shaping the government's relations with the other units of government in the federal system and with the American people as well. As the initial plans for the war were developed and as the first skirmishes were fought, just what pattern the government was following in developing its role was not at all clear. Some of the possible explanations for that lack of clarity have been advanced above. Perhaps all of them are wrong. It may be that the genius of the American system of government lies in the fact that it is not dogmatic, that it does not require explicitness, that it permits a role to be changed and altered as time and circumstances demand. A good case in point would be the federal role in education, which for many years was as obscure as the federal role in the poverty program is today and which only now is assuming a definite and reasonably clear form. The poverty program is in many respects merely an extension of the federal government's concern for education, ${ }^{62}$ so perhaps it is futile to expect its role to develop differently than that of its parent.

In any case, it will probably be a good while before a final description of the federal role in the poverty program can be formulated. What has been done so far in the war against poverty has been done on a "crash basis," as is usually the case in war, and with the same disregard for niceties that has marked government actions in other wars. As the war on poverty settles down from emphasis on "day-to-day action programs" and begins to undertake "comprehensive planning which resolves unmet needs" of the nation, ${ }^{63}$ however, greater attention will probably be given to the formalities and to an explication of role. Whatever finally evolves, it will no doubt show that in some ways the poverty program has introduced the federal government to a new role. Under its aegis, money has begun to flow directly to local community agencies with no way-stops in between; and those agencies must consist, in part at least, of representatives of the recipients of the government's aid. Both these features serve to set the poverty program aside from other government programs, and both have implications for the federal role in other action areas which it is still too early even to suggest. One can be sure at least that the example of the poverty program will not be missed. Indeed, it may be that in the end, the war on poverty will be known more for the alterations it introduced in the pattern of American government than for any of the very real contributions to American society it seems likely to make.

\footnotetext{
62 "The . . . attack on poverty under Mr. Shriver," the New York Times observed recently, "begins below kindergarten and goes all the way through the learning and earning years. About the only programs without a built-in education feature are those for the old and infirm." N.Y. Times, Jan. 12, 1966, p. 5r, col. 3 .

${ }^{68}$ Bensman \& Tobier, Anti-Poverty Progranming: A Proposal, Urban Affairs Quarterly, Sept. 1965, p. 54 , at 55 .
} 